\title{
IMPROVEMENT OF THE ASSESSMENT METHODS OF PRODUCT COMPETITIVENESS OF THE SPECIALIZED POULTRY ENTERPRISES
}

\author{
Tetyana Savchenko ${ }^{\text {, Nataliya Basiurkina², }{ }^{*} \text { Olga Rodina }^{3} \text {, Aleksy Kwilinski }}{ }^{4}$ \\ ${ }^{1}$ PhD, Assoc. Prof. Energodar Institute of Public and Municipal Administration named after \\ R. G. Khenoh «Classic Private University». Molodizhna str. 3a. Energodar. 71503. Ukraine. \\ Tel. +380660153141. E-mail savchenko1802@ukr.net \\ ${ }^{2}$ Dr, Assoc. Prof. Odessa National Academy of Food Technologies. Kanatna str. 112. Odessa. \\ 65039.Ukraine.Tel.+380987269600.E-mailnbas@email.ua \\ ${ }^{3}$ Postgraduate, senior teacher Energodar Institute of Public and Municipal Administration named \\ after R. G. Khenoh «Classic Private University». Molodizhna str., 3a. Energodar. 71503. Ukraine. \\ Tel.+380663010019. E-mail olga_gelevan@ukr.net \\ ${ }^{4}$ Ph.D., Prof. London Academy of Science and Business. Baker Street, London, England, \\ Tel. +44 754333 1714. E-mai: a.kwilinski@london-asb.co.uk
}

Received 2901 2019; accepted 14032019

\begin{abstract}
Assessment of the product competitiveness is a major multifactor task, which is reduced to interpretation and evaluation of set indicators that characterize the key product properties and form the level of its competitiveness. It is important objective to increase the level of objectification of assessment product competitiveness of specialized poultry enterprises by quality indicators. The aim of the research is to improve the assessment methods of product competitiveness of the specialized poultry enterprises. Main research results: developed the methodical approach to assess the product competitiveness, and it differs in the definition the level of product competitiveness based on the calculation of the composite indicator as a sum of weighted indicators, in view of the specific requirements for the products of specialized poultry enterprises.

Keywords: competitiveness of product, expert evaluation, consumer parameters, consumer price, trade mark, specialized poultry enterprises.
\end{abstract}

JEL Codes: D41, Q13, C63, L13.

\section{Introduction}

With the increased globalization of the economy, the term competitiveness has become ubiquitous. Most see the term as synonymous with productivity. Harvard's Michael Porter (1998) states, "The only meaningful concept of competitiveness at the national level is productivity" (Porter, 1998). The World Economic Forum's Global Competitiveness Report (2012) defines competitiveness as "the set of institutions, policies, and factors that determine the level of productivity of a country" (Schwab, 2012) and IMD's World Competitiveness Yearbook defines competitiveness

Copyright (C) 2019 The Authors. Published by Vytautas Magnus University, Lithuanian Institute of Agrarian Economics. This is an open access article distributed under the terms of the Creative Commons Attribution NonCommercial 4.0 (CC BY-NC 4.0) license, which permits unrestricted use, distribution, and reproduction in any medium, provided the original author and source are credited. The material cannot be used for commercial purposes.

* Corresponding author 
similarly, but more broadly, as how an "economy manages the totality of its resources and competencies to increase the prosperity of its population" (World Competitiveness Yearbook, 2012).

The performance success of any company depends on the product competitiveness it offers its customers. The assessment of the product competitiveness is a set of actions on choosing criteria (indicators) of competitiveness, the determination of the true values of these indicators for competitive products, and the comparison of values for the goods analyses with the goods taken as base ones. (Kobiliatska, 2003).

Consequently, the company competitiveness is an aggregate indicator of its competitiveness and its ability to respond promptly and fit into external environment changed. The product competitiveness is the most important concern for industry and is decided by the interaction of enterprise with the market environment (Takei, 1985).

Generally, the product competitiveness can be defined as a set of qualitative and price characteristics of products made according to the scheme of economic costs to meet the consumer's needs, complying with the competitive market requirements in comparison with similar products presented on it (Prodius, 1999; Zaitseva, Stradinya, 2017).

Pogrebnyak D. (2011) notes that the company competitiveness can be defined as a complex characteristic, which reflects the advantage of a set of its performance figures assessed, those determine the company success on a certain market for a certain period of time, regarding a number of competitors figures (Pogrebnyak, 2011). The methods for assessment of the product competitiveness are divided into qualitative and quantitative by means of assessment, and matrix, graphic and indicator ones by reporting of result (Ivanov, 2003; Stepanenko, 2015).

The competitiveness is persuasive power held by a bundle of design information. The product is bundle of design information. The Consumers process this information and create own satisfaction or expectation. Competitiveness is power of product (bundle of information) that persuades potential customers and makes exiting customers consent. However, competitiveness is difficult to be measured. In many cases, an overall evaluation must be made based on measurements of plural number of indicators. and the Competitiveness is measured at the levels of "product", "brand", "business", "industry" (Fujimoto, 2001).

Of course, the most objective methods for assessment are quantitative ones, but failure to express some characteristics of products with quantitative indicators requires the use of precisely qualitative methods for assessment. In this regard, the primary task of our research is to improve the objectification of the competitiveness assessment for the products of specialized poultry enterprises in terms of quality.

In conditions of increasing globalization on general level of competitiveness is affecting more factors, and therefore the question arises about the formation of a composite indicator of competitiveness and search for the most adequate requirements for methods of there assessment. Among the main ones, which are trying in a certain way to more systematically analyze and assess the factors affecting competitiveness (determine it level) should be highlighted the follow: methods for 
assessing the product competitiveness are based on their ranking, by sales volume, differential method, complex method and mixed method (Stepankova, 2012).

If the product competitiveness is considering, as a rule, they are determining the price and quality of execution. Influence of these indicators determines the place of a company on the market.

The price is a monetary expression of value, the amount of money has paid or received per unit of products or services. The quality of products or services is one of the most important factors for the successful business of any company. The quality is a set of properties and characteristics of the products, which determine ability to meet specific personal or production needs in accordance with their purpose (Chupyk, 2006).

Therefore, two main parameters determine the basis of the products competitiveness, they are consumer parameters and price. Among the products of the same destination more competitive in the market are owns the one that thanks to their properties brings the greatest effect in relation to the price of consumption. T. Melnyk and O. Xrystofor (2002) consider, that it is necessary to estimate additionally such indicator, as the level of the marketing environment, namely: advertising, company image, prestige of a trademark (Melnyk, 2002; Xrystofor, 2002).

So, from non-commodity factors of competitiveness (advertising activity, the prestige of the company) the indicator of the product competitiveness as "popularity of trade mark" is formed. This indicator at the same consumer parameters and price performs an important role in the installing the level of the product competitiveness.

Consequently, to manage of the product competitiveness it means to provide an optimal ratio of such parameters: improve the product quality, reduce the costs of reduction, increase the popularity of the trademark.

The aim of this research is to improve the assessment methods for the product competitiveness of the specialized poultry enterprises.

The object of the research is process of the assessing of product competitiveness of the specialized poultry enterprises. The research subject is the product competitiveness of the specialized poultry enterprises as an composite indicator based on the assessment of the consumer parameters of products, the consumer prices and the popularity of trade mark (brand).

\section{Research methodology}

The research is based on the dialectical method of knowing in economic processes and phenomena, their relationship, continuous development and systematic approach to study of the problem of improvement the assessment methods of product competitiveness. In order solving the tasks in the research, following scientific methods were used (for the analysis of indicators that form the level of product competitiveness), observation and survey (while collecting and grouping information about the consumer parameters of products of specialized poultry enterprises). 
To process the data presented in the research, such methods as comparison, grouping, generalization and the method of expert assessment (calculation of individual and group indicators of product competitiveness and for the assess the intra-group significance of each selected indicators), the combined calculation and graphing method for calculation the composite coefficient of product competitiveness and the plotting of a "product competitiveness triangle").

\section{Results}

To assess the competitiveness of products of the specialized poultry enterprises $\left(\mathrm{I}_{\mathrm{cp}}\right)$, it is proposed to use the system of scoring assessment based on the calculation of the composite indicator as a sum of weighted indicators such as: group indicator of competitiveness "consumer parameters of products" ( $\left.\mathrm{GI}_{\mathrm{ccp}}\right)$, indicator "consumer price" $\left(\mathrm{I}_{\mathrm{p}}\right)$, indicator "popularity of trade mark" $\left(\mathrm{I}_{\mathrm{ptm}}\right)$.

To obtain values of the individual indicators of group indicator "consumer parameters of products", indicator "consumer price" and indicator "popularity of trade mark", the score scale of 2 to 5 points was used, which is shown in Table 1. To assess the competitiveness of products was chosen the carcasses of chicken-broilers because this type of product is accounts for $80 \%$ of the total sales volume.

To determine the indicator "consumer price" the price of the company's products is compared, which is compared with the price of similar products of the main competitor.

Table 1. The scoring system of point the indicators of product competitiveness of the specialized poultry enterprises

\begin{tabular}{|c|c|c|c|c|}
\hline \multirow[t]{2}{*}{ Indicators } & \multicolumn{4}{|c|}{ Score, points } \\
\hline & 5 - "perfectly" & 4- "well" & 3 - "satisfactory" & 2 - "unsatisfactory" \\
\hline \multicolumn{5}{|c|}{ Group indicator of competitiveness «consumer parameters of product» $\left(\mathrm{GI}_{\mathrm{ccp}}\right)$} \\
\hline $\begin{array}{c}\text { The appearance } \\
\text { of the carcass } \\
\text { (Ac) }\end{array}$ & $\begin{array}{l}\text { The surface is } \\
\text { dry, the inner } \\
\text { surface is clean, } \\
\text { without clots of } \\
\text { blood. }\end{array}$ & $\begin{array}{l}\text { The surface is dry, } \\
\text { the inner surface is } \\
\text { clean, without } \\
\text { clots of blood. } \\
\text { Can be the minor } \\
\text { skin damage, } \\
\text { muscles and } \\
\text { bones, which is } \\
\text { the consequence } \\
\text { of the } \\
\text { dismemberment of } \\
\text { carcass. }\end{array}$ & $\begin{array}{l}\text { The surface is dry, } \\
\text { the inner surface is } \\
\text { clean, without } \\
\text { clots of blood. But } \\
\text { there are minor } \\
\text { injuries to the } \\
\text { skin, muscles and } \\
\text { bones. }\end{array}$ & $\begin{array}{l}\text { The surface is dry, } \\
\text { but the skin is faded, } \\
\text { perhaps there is } \\
\text { mold. There are } \\
\text { fractures to the } \\
\text { femur and tibia, } \\
\text { sharp edges of bones } \\
\text { and bone fragments, } \\
\text { traces of blows, deep } \\
\text { cuts of muscle tissue } \\
\text { and skin. }\end{array}$ \\
\hline $\begin{array}{l}\text { Condition of } \\
\text { skin }(\mathrm{Cs})\end{array}$ & $\begin{array}{l}\text { Clean, dry, no } \\
\text { scratches, no } \\
\text { ruptures, stains } \\
\text { and bruises. } \\
\text { For frozen } \\
\text { carcasses - } \\
\text { without freezer }\end{array}$ & $\begin{array}{l}\text { Clean, dry, no } \\
\text { ruptures, stains } \\
\text { and bruises, but } \\
\text { has minor } \\
\text { scratches. }\end{array}$ & $\begin{array}{l}\text { Clean, dry, no } \\
\text { stains and bruises, } \\
\text { but has minor } \\
\text { scratches } \\
\text { and ruptures }\end{array}$ & $\begin{array}{c}\text { Does not comply } \\
\text { with DSTU } \\
\text { 3143:2013. Covered } \\
\text { with mucus, } \\
\text { especially under the } \\
\text { wings and in the } \\
\text { groin, and in the }\end{array}$ \\
\hline
\end{tabular}


Management Theory and Studies for Rural Business and Infrastructure Development

ISSN 2345-0355. 2019. Vol. 41. No. 1: 43-61

Article DOI: https://doi.org/10.15544/mts.2019.05

\begin{tabular}{|c|c|c|c|c|}
\hline & $\begin{array}{l}\text { burn, for a } \\
\text { chilled - no sign } \\
\text { of freezing. }\end{array}$ & & & folds of the skin. \\
\hline $\begin{array}{l}\text { Color of skin } \\
\text { (Cls) }\end{array}$ & $\begin{array}{l}\text { From white to } \\
\text { yellow. }\end{array}$ & $\begin{array}{l}\text { From white to } \\
\text { yellow with a } \\
\text { slight shade. }\end{array}$ & $\begin{array}{l}\text { From white to } \\
\text { yellow, but with a } \\
\text { significant shade } \\
\text { close to gray }\end{array}$ & $\begin{array}{l}\text { A mucous surface } \\
\text { and a yellow-gray } \\
\text { color }\end{array}$ \\
\hline Smell (S) & $\begin{array}{l}\text { Characteristically } \\
\text { of benign for } \\
\text { poultry meat, no } \\
\text { other smells }\end{array}$ & $\begin{array}{l}\text { Characteristically } \\
\text { of benign for } \\
\text { poultry meat, but } \\
\text { has other slight } \\
\text { smell }\end{array}$ & $\begin{array}{l}\text { In the thoracic } \\
\text { cavity and } \\
\text { abdominal cavity } \\
\text { is smell }\end{array}$ & $\begin{array}{l}\text { The putrid smell } \\
\text { from the surface of } \\
\text { the carcass and } \\
\text { inside the muscle, } \\
\text { the most pronounced } \\
\text { in the chest and } \\
\text { abdominal cavity }\end{array}$ \\
\hline $\begin{array}{l}\text { Degree of } \\
\text { removal the } \\
\text { chicken feather } \\
\text { (Dcf) }\end{array}$ & $\begin{array}{l}\text { The chicken } \\
\text { feather is } \\
\text { completely } \\
\text { removed }\end{array}$ & $\begin{array}{l}\text { The chicken } \\
\text { feather is } \\
\text { completely } \\
\text { removed, but there } \\
\text { are single residues }\end{array}$ & $\begin{array}{l}\text { The chicken } \\
\text { feather is } \\
\text { completely } \\
\text { removed, but there } \\
\text { is a small amount } \\
\text { the remains of the } \\
\text { pen scattered on } \\
\text { the surface of the } \\
\text { carcass }\end{array}$ & $\begin{array}{l}\text { The feathers of the } \\
\text { chicken are not } \\
\text { completely removed, } \\
\text { there are significant } \\
\text { feathers residues on } \\
\text { the wings and tail }\end{array}$ \\
\hline $\begin{array}{l}\text { Consistency of } \\
\text { chilled meat } \\
(\mathrm{Ccm})\end{array}$ & $\begin{array}{l}\text { The muscles are } \\
\text { dense and } \\
\text { resilient; if press } \\
\text { the finger on the } \\
\text { chilled meat the } \\
\text { small pit which } \\
\text { was formed is } \\
\text { quickly aligned }\end{array}$ & $\begin{array}{l}\text { The muscles are } \\
\text { less dense and less } \\
\text { resilient; but if } \\
\text { press the finger on } \\
\text { the chilled meat } \\
\text { the small pit } \\
\text { which was formed } \\
\text { is quickly aligned }\end{array}$ & $\begin{array}{c}\text { The muscles are } \\
\text { dense and } \\
\text { resilient, } \\
\text { if press the finger } \\
\text { on the chilled meat } \\
\text { the small pit which } \\
\text { was formed is } \\
\text { more slower } \\
\text { aligned (within } \\
\text { one minute) }\end{array}$ & $\begin{array}{l}\text { The muscles are } \\
\text { flabby; when pressed } \\
\text { with a finger- the } \\
\text { small pit is formed, } \\
\text { which is no aligned }\end{array}$ \\
\hline $\begin{array}{c}\text { Color of } \\
\text { subcutaneous } \\
\text { and internal fat } \\
\text { (Cf) }\end{array}$ & $\begin{array}{c}\text { Pale yellow or } \\
\text { yellow }\end{array}$ & $\begin{array}{l}\text { Pale yellow or } \\
\text { yellow with a } \\
\text { slight shade. }\end{array}$ & $\begin{array}{l}\text { Pale yellow with a } \\
\text { significant shade } \\
\text { close to gray }\end{array}$ & $\begin{array}{l}\text { Pale yellow color, } \\
\text { and the internal } \\
\text { adipose tissue is } \\
\text { yellowish-white with } \\
\text { gray shade }\end{array}$ \\
\hline $\begin{array}{l}\text { State of the bone } \\
\text { system (Cbs) }\end{array}$ & $\begin{array}{l}\text { The bone system } \\
\text { without fractures } \\
\text { and deformities }\end{array}$ & $\begin{array}{c}\text { The bone system } \\
\text { without fractures } \\
\text { with minor } \\
\text { deformation }\end{array}$ & $\begin{array}{c}\text { The bone system } \\
\text { has a slight } \\
\text { fracture and } \\
\text { deformation }\end{array}$ & $\begin{array}{c}\text { The bone system has } \\
\text { an explicit fracture } \\
\text { and deformation }\end{array}$ \\
\hline $\begin{array}{l}\text { The information } \\
\text { content of the } \\
\text { marking (Mi) }\end{array}$ & $\begin{array}{l}\text { Complies with } \\
\text { the law of } \\
\text { Ukraine } \\
\text { «On protection } \\
\text { of consumer } \\
\text { rights» and } \\
\text { technical } \\
\text { requirements } \\
\text { regarding the }\end{array}$ & $\begin{array}{l}\text { Complies with the } \\
\text { law of Ukraine } \\
\text { «On protection of } \\
\text { consumer rights» } \\
\text { and technical } \\
\text { requirements } \\
\text { regarding the rules } \\
\text { of food labeling, } \\
\text { the availability of }\end{array}$ & $\begin{array}{l}\text { Complies with the } \\
\text { law of Ukraine } \\
\text { «On protection of } \\
\text { consumer rights» } \\
\text { and technical } \\
\text { requirements } \\
\text { regarding the rules } \\
\text { of food labeling }\end{array}$ & $\begin{array}{l}\text { Does not comply } \\
\text { with the law of } \\
\text { Ukraine «On } \\
\text { protection of } \\
\text { consumer rights» } \\
\text { and partially meets } \\
\text { the technical } \\
\text { requirements } \\
\text { regarding the rules }\end{array}$ \\
\hline
\end{tabular}


Tetyana Savchenko, Nataliya Basiurkina, Olga Rodina, Aleksy Kwilinski. Improvement of the Assessment Methods of Product Competitiveness of the Specialized Poultry Enterprises

\begin{tabular}{|c|c|c|c|c|}
\hline & $\begin{array}{l}\text { rules of food } \\
\text { labeling, the } \\
\text { availability of } \\
\text { information } \\
\text { about the } \\
\text { competitive } \\
\text { advantages of } \\
\text { product and } \\
\text { advertising } \\
\text { slogans }\end{array}$ & $\begin{array}{c}\text { information about } \\
\text { the competitive } \\
\text { advantages of } \\
\text { product }\end{array}$ & & $\begin{array}{l}\text { of food labeling, is } \\
\text { estimated as a } \\
\text { normative indicator } \\
\text { equal to zero }\end{array}$ \\
\hline $\begin{array}{l}\text { Information and } \\
\text { artistic } \\
\text { expressiveness } \\
\text { of packaging } \\
\text { (EPia) }\end{array}$ & $\begin{array}{l}\text { The package has } \\
\text { attractive } \\
\text { appearance, with } \\
\text { compliance the } \\
\text { ergonomic } \\
\text { requirements, } \\
\text { clearly decorated } \\
\text { label, which } \\
\text { contains the } \\
\text { originally of } \\
\text { artistic design }\end{array}$ & $\begin{array}{c}\text { The usual } \\
\text { appearance of the } \\
\text { packaging, high- } \\
\text { quality printing } \\
\text { performance of the } \\
\text { label, the } \\
\text { information is } \\
\text { clear and easy to } \\
\text { read }\end{array}$ & $\begin{array}{l}\text { The usual } \\
\text { appearance of the } \\
\text { package, does not } \\
\text { met the quality of } \\
\text { polygraphic } \\
\text { execution of label, } \\
\text { pale color or } \\
\text { wrong } \\
\text { combination of } \\
\text { colors }\end{array}$ & $\begin{array}{l}\text { The quality of label } \\
\text { was not adhere, no } \\
\text { resistance to damage } \\
\text { and to storage the } \\
\text { initial appearance of } \\
\text { the package, the } \\
\text { information is fuzzy }\end{array}$ \\
\hline \multicolumn{5}{|c|}{ Indicator "popularity of trade mark" $\left(\mathrm{I}_{\mathrm{ptm}}\right)$} \\
\hline $\begin{array}{c}\text { General } \\
\text { characteristics }\end{array}$ & $\begin{array}{l}\text { A trademark is } \\
\text { well-known, } \\
\text { attractive, } \\
\text { prestigious }\end{array}$ & $\begin{array}{l}\text { A trademark is } \\
\text { well-known, but } \\
\text { not enough } \\
\text { attractive }\end{array}$ & $\begin{array}{l}\text { A trademark is } \\
\text { little-known and } \\
\text { not enough } \\
\text { attractive }\end{array}$ & $\begin{array}{l}\text { A trademark is } \\
\text { unknown }\end{array}$ \\
\hline \multicolumn{5}{|c|}{ Indicator "consumer price" $\left(\mathrm{I}_{\mathrm{p}}\right)$} \\
\hline The price scale & $\begin{array}{c}\text { The price is } \\
\text { lower than have } \\
\text { a competitor }\end{array}$ & $\begin{array}{l}\text { The price of } \\
\text { products is the } \\
\text { same as have a } \\
\text { competitor }\end{array}$ & $\begin{array}{l}\text { The price of } \\
\text { products is higher } \\
\text { than that have a } \\
\text { competitor }\end{array}$ & $\begin{array}{l}\text { The price of } \\
\text { products is } 50 \\
\text { percent is higher } \\
\text { than have a } \\
\text { competitors }\end{array}$ \\
\hline
\end{tabular}

In order to determine the weighted coefficients of the group indicators of the product competitiveness, it is recommended that experts be interviewed in the form of interviews (Kotler, 2007; Mihalovich, 2016). For obtaining the expert assessment, the Delphi method was proposed, which is a kind of method of collective expert assessments, as it has quite significant advantages (Beshelev, 1980; Kapelko, 2016). The total number of interviewed experts are 10 persons, who are middle-level employees and specialists. Assessment criteria of the weight of selected group indicators that influencing the level of product competitiveness was defined for a 10point scale (Table 2).

Table 2. Assessment criteria of the weight of indicators that influencing the level of product competitiveness for a 10-point scale

\begin{tabular}{|c|c|}
\hline Scale, points & Assessment criteria of the weight of indicators \\
\hline 10 & $\begin{array}{c}\text { The importance of the indicator has a decisive influence on the level of product } \\
\text { competitiveness }\end{array}$ \\
\hline 9 & $\begin{array}{c}\text { The importance of the indicator has a essential influence on the level of product } \\
\text { competitiveness }\end{array}$ \\
\hline
\end{tabular}


Management Theory and Studies for Rural Business and Infrastructure Development

ISSN 2345-0355. 2019. Vol. 41. No. 1: 43-61

Article DOI: https://doi.org/10.15544/mts.2019.05

\begin{tabular}{|c|c|}
\hline 8 & $\begin{array}{c}\text { The importance of the indicator has a significant influence on the level of product } \\
\text { competitiveness }\end{array}$ \\
\hline 7 & $\begin{array}{l}\text { The importance of the indicator has a high influence on the level of product } \\
\text { competitiveness }\end{array}$ \\
\hline 6 & $\begin{array}{c}\text { The importance of the indicator has a higher than average influence on the level } \\
\text { of product competitiveness }\end{array}$ \\
\hline 5 & $\begin{array}{l}\text { The value of the indicator has a medium influence on the level of product } \\
\text { competitiveness }\end{array}$ \\
\hline 4 & $\begin{array}{l}\text { The importance of the indicator has a below average influence on the level of } \\
\text { product competitiveness }\end{array}$ \\
\hline 3 & $\begin{array}{c}\text { The importance of the indicator has a insignificant influence on the level of } \\
\text { product competitiveness }\end{array}$ \\
\hline 2 & $\begin{array}{l}\text { The importance of the indicator has almost does not influence on the level of } \\
\text { product competitiveness }\end{array}$ \\
\hline 1 & $\begin{array}{l}\text { The importance of the indicator has does not influence on the level of product } \\
\text { competitiveness }\end{array}$ \\
\hline
\end{tabular}

The obtained experts assessments of the weight $q_{i j}$ of each $j$ group indicator in points are averaged and normalized to obtain the weight coefficient $q_{j n}$. To analyze the coherence of experts the coefficient of variation of the answer variants $(v)$ is used.

The group indicator of competitiveness "consumer parameters of products" is calculated as a sum of weighted individual indicators.

The calculation of the weight coefficients for the product competitiveness and individual indicators of the group indicator "consumer parameters of product" of specialized poultry enterprise based on the expert's answers determining the weight of the coefficients and the variation coefficient are given in Table 3.

Table 3. Calculation of the weight coefficient of the product competitiveness of specialized poultry enterprise

\begin{tabular}{|c|c|c|c|c|c|c|c|c|c|c|c|c|c|c|}
\hline \multirow[t]{2}{*}{ 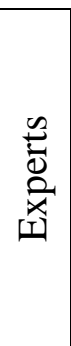 } & \multirow[t]{2}{*}{ 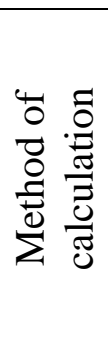 } & \multicolumn{10}{|c|}{$\begin{array}{l}\text { Weighting coefficients of individual indicators of the group } \\
\text { indicator "consumer parameters of product" }\end{array}$} & \multicolumn{3}{|c|}{$\begin{array}{c}\text { Weighting } \\
\text { coefficients of } \\
\text { indicators of the } \\
\text { product } \\
\text { competitiveness }\end{array}$} \\
\hline & & $\mathrm{Ac}$ & Cs & $\mathrm{Cls}$ & $\mathrm{S}$ & Dcf & $\begin{array}{c}\mathrm{Cc} \\
\mathrm{m}\end{array}$ & $\mathrm{Cf}$ & $\mathrm{Cbs}$ & $\mathrm{Mi}$ & EPia & $\mathrm{GI}_{\mathrm{ccp}}$ & $\mathrm{I}_{\mathrm{ptm}}$ & $I_{p}$ \\
\hline 1 & \multirow{10}{*}{ 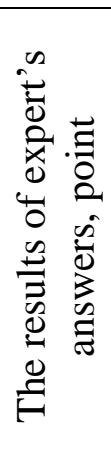 } & 10 & 8 & 5 & 8 & 6 & 9 & 7 & 4 & 8 & 4 & 8 & 6 & 7 \\
\hline 2 & & 8 & 7 & 7 & 10 & 4 & 9 & 6 & 4 & 6 & 3 & 9 & 4 & 9 \\
\hline 3 & & 7 & 8 & 7 & 8 & 5 & 8 & 8 & 6 & 7 & 4 & 10 & 5 & 5 \\
\hline 4 & & 10 & 10 & 6 & 7 & 3 & 10 & 5 & 5 & 6 & 3 & 10 & 3 & 7 \\
\hline 5 & & 9 & 9 & 4 & 10 & 4 & 9 & 7 & 4 & 5 & 6 & 8 & 4 & 6 \\
\hline 6 & & 8 & 5 & 8 & 9 & 5 & 8 & 6 & 3 & 7 & 3 & 9 & 4 & 8 \\
\hline 7 & & 8 & 6 & 5 & 10 & 3 & 10 & 7 & 5 & 8 & 3 & 10 & 5 & 6 \\
\hline 8 & & 9 & 9 & 6 & 10 & 4 & 8 & 6 & 4 & 5 & 5 & 7 & 4 & 8 \\
\hline 9 & & 9 & 8 & 8 & 8 & 5 & 7 & 8 & 4 & 8 & 4 & 10 & 3 & 7 \\
\hline 10 & & 10 & 8 & 6 & 9 & 3 & 7 & 5 & 3 & 6 & 5 & 9 & 6 & 6 \\
\hline
\end{tabular}


Tetyana Savchenko, Nataliya Basiurkina, Olga Rodina, Aleksy Kwilinski. Improvement of the Assessment Methods of Product Competitiveness of the Specialized Poultry Enterprises

\begin{tabular}{|c|c|c|c|c|c|c|c|c|c|c|c|c|c|c|}
\hline$q_{i j}$ & $q_{i j}=q_{1}+q_{2} \ldots q_{n} / n$ & 8.80 & 7.80 & 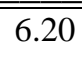 & 8.90 & 4.20 & $\overline{8.50}$ & "6.50 & 4.20 & $\overline{6.60}$ & 4.00 & $\overline{99.00}$ & $\overline{4.30}$ & 6.90 \\
\hline$q_{j H}$ & $q_{j t}=q_{i j} / \sum q_{i j}$ & 0.14 & 0.12 & 0.09 & 0.14 & 0.06 & 0.13 & 0.10 & 0.06 & 0.10 & 0.06 & 0.44 & 0.22 & 0.34 \\
\hline$\sigma$ & $\begin{array}{c}\sigma=\sqrt{D\left(q_{i j}\right)} \\
D\left(q_{i j}\right)=\frac{1}{n} \sum_{i=1}^{n}\left(q_{i j}-\overline{q_{i j}}\right) \\
\text { where } n- \\
\text { number of } \\
\text { experts }\end{array}$ & 0.96 & 1.96 & 1.56 & 1.09 & 0.96 & 1.05 & 1.05 & 0.76 & 1.24 & 1.00 & 1.12 & 1.02 & 1.26 \\
\hline $\mathrm{v}$ & $v=\sigma / q_{j}$ & 0.11 & 0.25 & 0.25 & 0.12 & 0.23 & 0.12 & 0.16 & 0.18 & 0.19 & 0.25 & 0.12 & 0.23 & 0.18 \\
\hline
\end{tabular}

The degree of coherence of experts is determined by the following characteristics of the coefficient of variation (Vasylieva, 2015; Weiss, 2010):

$\mathrm{v} \leq 0,10$ - coherence is high;

$\mathrm{v}=0,11-0,15-$ coherence is above average;

$\mathrm{v}=0,16-0,25-$ coherence is medium;

$\mathrm{v}=0,26-0,35-$ coherence is below average;

$\mathrm{v}>0,35$ - coherence is below the permissible norm.

The Table 3 shows that coefficient variation is changing in the norm (obtained coefficients variation is not higher 0.25 ).

The obtained distribution of the weight criteria of competitiveness was confirmed by the survey of consumers of products, which were almost unanimous in their statements, both in Ukraine and in Poland (Fig. 1).

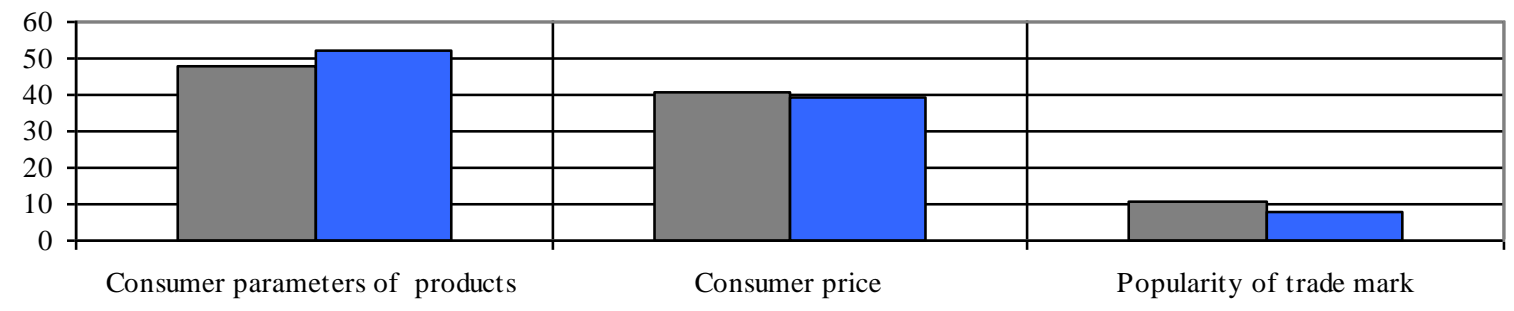

$\square$ Ukraine $\square$ Poland

Figure 1. Distribution of the weight criteria of competitiveness after survey of consumers of products in Ukraine and in Poland

According to the results of the expert appraisal, the following relation of the group indicator "consumer parameters of product" $\left(\mathrm{GI}_{\mathrm{ccp}}\right)$, which can be formed into a mathematical model, is recommended (formula 1):

$$
\begin{aligned}
& G I_{c c p}=0.13 * A c+0.12 * C s+0.09 * C l s+0.14 * S+0.06 * D c f+0.13 C c m+0.10 * C f+ \\
& 0.06 * C b s+0.10 * M i+0.06 * E P i a
\end{aligned}
$$

The composite indicator of product competitiveness $\left(\mathrm{I}_{\mathrm{cp}}\right)$ can be expressed as follows (formula 2): 


$$
I_{c p}=0.44 * G I_{c c p}+0.22 * I_{p t m}+0.34 * I_{p},
$$

where $I_{c p}$ - composite indicator of the product competitiveness;

$G I_{c c p}$ - group indicator of competitiveness "consumer parameters of products";

$I_{p t m}$ - indicator "popularity of trade mark";

$I_{p}$-indicator "consumer price"

We calculate the product competitiveness for carcasses of chicken-broilers chilled of trade mark "Znatna kurka" (Ptahokompleks Dniprovsky LLC - competitor $1\left(\mathrm{C}_{1}\right)$ in comparison with the products of the main competitor trade mark "Nasha Ryaba" brand (Mironivsky Hliboproduct PRJSC - competitor $2\left(\mathrm{C}_{2}\right)$ is prepared (Table 4).

Table 4. Calculation of the composite indicator of product competitiveness

\begin{tabular}{|c|c|c|c|c|c|c|c|}
\hline \multirow[t]{2}{*}{ Indicators } & \multicolumn{2}{|c|}{ Valuation, points } & \multirow[t]{2}{*}{$\begin{array}{l}\text { Weighting, } \\
\text { points }\end{array}$} & \multicolumn{2}{|c|}{$\begin{array}{c}\text { Weighted } \\
\text { assessment of } \\
\text { individual } \\
\text { indicators, points }\end{array}$} & \multicolumn{2}{|c|}{$\begin{array}{c}\text { Weighted } \\
\text { assessment of } \\
\text { indicators of the } \\
\text { product } \\
\text { competitiveness, } \\
\text { points }\end{array}$} \\
\hline & $\mathrm{C}_{1}$ & $\mathrm{C}_{2}$ & & $\mathrm{C}_{1}$ & $\mathrm{C}_{2}$ & $\mathrm{C}_{1}$ & $\mathrm{C}_{2}$ \\
\hline $\begin{array}{c}\text { Group indicator } \\
\text { of } \\
\text { competitiveness } \\
\text { «consumer } \\
\text { parameters of } \\
\text { product» }\end{array}$ & - & - & 0.44 & 4.16 & 4.81 & 1.83 & 2.12 \\
\hline $\begin{array}{l}\text { The appearance } \\
\text { of the carcass }\end{array}$ & $\begin{array}{c}(4+4+4+5+ \\
+3+3+4+4+ \\
+4+5) / 10=4.00\end{array}$ & $\begin{array}{c}(5+5+5+5+ \\
+4+5+5+5+ \\
+5+5) / 10=4.90\end{array}$ & 0.14 & 0.56 & 0.64 & - & - \\
\hline Condition of skin & $\begin{array}{c}(5+3+3+4+ \\
+3+3+4+4+ \\
+4+4) / 10=3.70 \\
\end{array}$ & $\begin{array}{c}(5+5+5+4+ \\
+5+5+5+4+ \\
+5+5) / 10=4.80\end{array}$ & 0.12 & 0.44 & 0.58 & & \\
\hline Color of skin & $\begin{array}{c}(5+4+4+5+ \\
+3+5+4+4+ \\
+5+4) / 10=4.30\end{array}$ & $\begin{array}{c}(5+5+5+5+ \\
+4+5+5+5+ \\
+5+5) / 10=4.90\end{array}$ & 0.09 & 0.38 & 0.44 & & \\
\hline Smell & $\begin{array}{c}(4+4+3+5+ \\
+4+5+4+3+ \\
+5+4) / 10=4.10\end{array}$ & $\begin{array}{c}(5+5+5+5+ \\
+5+5+5+5+ \\
+5+4) / 10=4.90\end{array}$ & 0.14 & 0.57 & 0.69 & & \\
\hline $\begin{array}{c}\text { Degree of } \\
\text { removal the } \\
\text { chicken feather }\end{array}$ & $\begin{array}{c}(5+5+4+5+ \\
+4+5+5+4+ \\
+4+4) / 10=4.50\end{array}$ & $\begin{array}{c}(4+5+5+5+ \\
+5+5+5+4+ \\
+5+5) / 10=4.80\end{array}$ & 0.06 & 0.27 & 0.28 & & \\
\hline $\begin{array}{c}\text { Consistency of } \\
\text { chilled meat }\end{array}$ & $\begin{array}{c}(5+4+4+5+ \\
+5+4+4+5+ \\
+4+4) / 10=4.40\end{array}$ & $\begin{array}{c}(5+5+5+5+ \\
+5+4+5+4+ \\
+5+5) / 10=4.80\end{array}$ & 0.13 & 0.57 & 0.62 & & \\
\hline $\begin{array}{c}\text { Color of } \\
\text { subcutaneous } \\
\text { and internal fat }\end{array}$ & $\begin{array}{c}(5+4+4+5+ \\
+4+4+4+5+ \\
+4+4) / 10=4.30\end{array}$ & $\begin{array}{c}(5+5+4+5+ \\
+5+5+5+4+ \\
+5+5) / 10=4.80\end{array}$ & 0.10 & 0.43 & 0.48 & & \\
\hline State of the bone & $(4+5+5+4+$ & $(5+5+5+4+$ & 0.06 & 0.24 & 0.28 & & \\
\hline
\end{tabular}


Tetyana Savchenko, Nataliya Basiurkina, Olga Rodina, Aleksy Kwilinski. Improvement of the Assessment Methods of Product Competitiveness of the Specialized Poultry Enterprises

\begin{tabular}{|c|c|c|c|c|c|c|c|}
\hline system & $\begin{array}{c}+3+4+4+4+ \\
+4+4) / 10=4.10\end{array}$ & $\begin{array}{c}+5+4+5+5+ \\
+4+5) / 10=4.70\end{array}$ & & & & & \\
\hline $\begin{array}{l}\text { The information } \\
\text { content of the } \\
\text { marking }\end{array}$ & $\begin{array}{c}(5+5+4+4+ \\
+5+5+5+4+ \\
+4+5) / 10=4.60\end{array}$ & $\begin{array}{c}(5+5+5+5+ \\
+5+5+5+5+ \\
+5+5) / 10=5.00\end{array}$ & 0.10 & 0.46 & 0.50 & & \\
\hline $\begin{array}{l}\text { Information and } \\
\text { artistic } \\
\text { expressiveness of } \\
\text { packaging }\end{array}$ & $\begin{array}{c}(4+4+4+ \\
+4+3+4+4+4+ \\
+5+4) / 10=4.00\end{array}$ & $\begin{array}{c}(5+5+5+5+ \\
+5+5+5+5+ \\
+5+5) / 10=5.00\end{array}$ & 0.06 & 0.24 & 0.30 & & \\
\hline $\begin{array}{l}\text { Indicator } \\
\text { "popularity of } \\
\text { trade mark" }\end{array}$ & 4.00 & 5.00 & 0.22 & - & - & 0.88 & 1.10 \\
\hline $\begin{array}{l}\text { Indicator } \\
\text { "consumer } \\
\text { price" }\end{array}$ & 5.00 & 4.00 & 0.34 & - & - & 1.70 & 1.36 \\
\hline $\begin{array}{c}\text { Composite } \\
\text { indicator of } \\
\text { product } \\
\text { competitiveness }\end{array}$ & - & - & 1.0 & - & - & 4.41 & 4.58 \\
\hline
\end{tabular}

After calculation of the competitiveness coefficient of the company products, the obtained score and the maximum possible (5 points) are compared and establish the level of its competitiveness is defined:

- from 0 to 1 point - the products are uncompetitive;

- from 1 to 3 points - the level of the product competitiveness is below the average;

- from 3 to 4 points - the level of the product competitiveness is average;

- from 4 to 4.5 points - the level of the product competitiveness is above average;

- from 4.6 to 5 points - the high level of the product competitiveness;

- 5 points - the highest level of the product competitiveness ("example of products").

In view of the results what were obtained on the basis of the composite indictor of product competitiveness, the level of competitiveness of the enterprises: the trade mark "Znatna Kurka" (Ptahokompleks Dniprovsky LLC) can be assessed as an above average level of the product competitiveness $-4.41(\approx 4.40)$ points and the trade mark "Nasha Ryaba" brand (Mironivsky Hliboproduct PRJSC) can be assessed as the high level of the product competitiveness -4.58 points $(\approx 4.60)$ (Fig. 2$)$. 


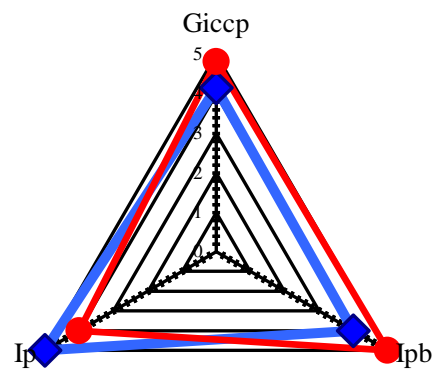

$\diamond$ Trade mark "Znatna Kurka" $\multimap-$ Trade mark "Nasha Ryaba"

Figure 2. The triangles of product competitiveness (carcasses of chicken-broilers chilled)

\section{Conclusions}

1. The analysis of modern approaches to assessment of the product competitiveness showed that none of the approach known is not adapted to assess the competitiveness of products of the specialized poultry enterprises. To improve the objectivity of assessment of the product competitiveness of the specialized poultry enterprise, it was proposed to use a system of indicators in view of the consumer parameters of product, consumer prices and the popularity of trade mark manufacturer.

2. The methodical approach to assessment of product competitiveness of the specialized poultry enterprises is developed which differs in determining the level of product competitiveness based on the calculation of composite indicator as a sum of weighted indicators in view of the specific requirements for the products what were made by the specialized poultry enterprises. The assessment results are represented by a triangle, the vertices of which are three indicators (indicator "consumer parameters of products", indicator "consumer price" and indicator "popularity of trade mark") that are underlie the assessment of the product competitiveness.

3. The level of product competitiveness of trade mark "Znatna Kurka" (Ptahokompleks Dniprovsky LLC) and trade mark "Nasha Ryaba" brand (Mironivsky Hliboproduct PRJSC) was assessed by the combined calculation and graphic method. It was defined that the level of product competitiveness of trade mark "Znatna Kurka" is above average and the trade mark "Nasha Ryaba" is high. And it is allowing the chance for both enterprises to compete successfully the local markets at the expense of less transportation costs.

\section{References}

Chupyk, G.R. (2006). Scientific approaches to the definition of "competition" and "competitiveness" categories // Visnyk Lvivskoyi KA. No. 22: 55-58.

Ivanov, Yu. B. (2003). Enterprise competitiveness: assessment, diagnostics, strategy. Kharkiv: KHGEY. 349 p. 
Fujimoto, Takahiro (2001). Concept of Competitiveness and Its Factors Business. https://ocw.u-tokyo.ac.jp/lecture_files/eco_01/7/notes/en/BusinessAdministration1_07.pdf [24 01 2019]

Kobiliatska, L. S. (2003). Competitiveness Management. - Kyiv: Zovnishnya torgivlya. 304 p. Kotler, F. (2007). Basics of Marketing. - Moskow: Publishing house "William". 656 p.

Mihalovich, M. (2016). Performance Comparison of Multiple Discriminant Analysis and Logit Models in Bankruptcy Prediction // Economics and Sociology. No. 9(4): 101-118. doi:10.14254/2071-789X.2016/9-4/6 [24 01 2019]

Melnyk, T. S., Xrystofor, O. V. (2002). Comprehensive assessment of the competitiveness of goods in the modern market // Visnyk VPI. No. 3: 23-28.

Prodius, Yu. I. (1999). The formation of a system for ensuring the competitiveness of industry. - Odessa: Astroprint. 72 p.

Pogrebnyak, D.V. (2011). The methods of diagnostics of enterprise competitiveness // Problemu pidvushchennya efektuvnosti infrastrukturi. Zbirnuk naukovih prats. No. 32: 45-51.

Porter, M.E. (1998). The competitive Advantage of Nations. - New York: Free Press. https://hbr.org/1990/03/the-competitive-advantage-of-nations [29 12 2018].

Stepanenko, T. O. (2015). The analysis of functional relationships of elements in integrated system of materials management // Technology audit and production reserves. No. 2/6(22): 58-62. - https://doi.org/10.15587/2312-8372.2015.41753 [29 12 2018]

Stepankova, A. A. (2012). Methods of assessment of the product competitiveness // Efektyvna ekonomika. No. 2. - http://www.economy.nayka.com.ua/?op=1\&z=954 [05 03 2019]

Schwab, Klaus (2012). "Global Competitiveness Report 2012- 2013" (World Economic Forum, September 2012). - http://reports.weforum.org/global-competitivenessreport-2012-2013 [12 $012019]$

Vasylieva, N. K., Vinichenko, I. I., Katan, L. I. (2015). Economic and mathematical evaluation of Ukrainian agrarian market by branches // Economic Annals-XXI. No. 9-10: 41-44.

Weiss, Dan (2010). Cost Behavior and Analysts' Earnings Forecasts // The Accounting Review. Vol. 85. No. 4: 1441-1471. - https://doi.org/10.2308/accr.2010.85.4.1441 [12 01 2019].

World Competitiveness Yearbook. (2012). - http://www.imd.org/wcc/wcy-worldcompetitivenessyearbook [12 012019$]$

Zaitseva, E., Stradinya, S. (2017). Innovative clustering and its development factors as a source of Latvia's competitiveness // Economic Annals-XXI. No. 168 (11-12): 28-32. https://orcid.org/0000-0003-3409-3922 [12 01 2019]. 


\title{
PRODUKTU KONKURENCINGUMO VERTINIMO METODŲ TOBULINIMAS SPECIALIZUOTOSE PAUKŠTININKYSTĖS İMONËSE
}

\author{
Tetjana Savčenko ${ }^{1}$, Natalija Basiurkina ${ }^{2}$, Olga Rodina $^{3}$, Oleksiy Kwilinski ${ }^{4}$ \\ ${ }^{1,3}$ Energodar viešojo administravimo institutas, Ukraina, ${ }^{2}$ Odesos Nacionaline maisto technologiju \\ akademija, Ukraina, ${ }^{4}$ Londono mokslo ir verslo akademija, Jungtiné Karalyste
}

Gauta 2901 2019; priimta 14032019

\section{Santrauka}

Produktų konkurencingumo vertinimas - tai svarbi užduotis, kurią sudaro daugybè veiksnių ir kurios metu aiškinami ir vertinami tam tikri nustatyti rodikliai, apibūdinantys pagrindines produkto savybes ir padedantys nustatyti jo konkurencingumo lygi. Svarbus tokio vertinimo uždavinys - užtikrinti kuo didesnị objektyvumo lygi vertinant produkto konkurencingumą specializuotose paukštininkystės įmonèse, naudojant kokybès rodiklius.

Šio tyrimo tikslas - patobulinti produktų konkurencingumo vertinimo metodus specializuotose paukštininkystès įmonėse, atsižvelgiant ị produktų vartojimo parametrus bei jų svorị. Pagrindiniai tyrimo rezultatai: sukurta produkto konkurencingumo vertinimo metodika, padedanti nustatyti produkto konkurencingumo lygi atlikus integruoto rodiklio, kaip svertinių rodiklių sumos, skaičiavimus, atsižvelgiant i specialius reikalavimus, taikomus produktams specializuotose paukštininkystès įmonèse.

Raktažodžiai: produktu konkurencingumas, ekspertu vertinimas, vartojimo parametrai, pardavimo kaina, prekès ženklas, specializuotos paukštininkystès ịmonès.

JEL kodai: D41, Q13, C63, L13.

* Autorius pasiteirauti 